\title{
CUSTOMER PREFERENCES TOWARDS \\ LIFE INSURANCE AS A SAVING ALTERNATIVE
}

* SANJAY MANOCHA

\begin{abstract}
The world "Fear" has only four alphabets like love but both of them are having very different meaning. Whatever man (male or female) does for the love of their families always starts with the background of fear. Generally so many times we have been asking ourselves that, what will happen if we were not there, but we keep on asking rather than doing something for it. Time is precious, it never stops for any one and we are living in the world of uncertainty; the uncertainty of job, the uncertainty of money, the uncertainty of property and like this the story continue for the whole life of a man.

How you can save your hard earned money? Or shall I say where you can invest? The answer to these questions is Banks, Post Offices, Equity, Mutual Funds, Capital Goods and Insurance.

Except insurance all the investment alternatives involves risk and the only rule that prevails is high risk high profit, if the economic circumstance is not favoring our investment we will loose our hard earned money, further more all these investment plans are for the short period, on the other hand Insurance has a long term perspective. As investment, it not only covers the risk of your life, rather it also secures the future of your loved ones.

The idea is to derive two basic investment need from insurance; one is the investment that means the returns on his money.

The other aspect of investment is assurance from the investment that this is the amount you will be getting.

In view of these insights, insurance emerges as the combination of both Investment and assurance.

$$
\text { Insurance }=\text { Investment }+ \text { Assurance }
$$

In view of the important role of insurance sector in savings and future planning, in this paper a study has been conducted to know the customer preferences towards life insurance among other saving alternatives.

* M.Phil, MBA, PGDRM, OLDPE

Sr. Lecturer - Bharati Vidyapeeth University Institute of Management \& Research, New Delhi

A-4, Paschim Vihar, New Rohtak Road, New Delhi, Mob : 09873030688

E-mail: manochas26@gmail.com
\end{abstract}




\section{Introduction}

\subsection{Insurance}

The business of insurance is related to the protection of the economic values of assets. Every asset has a value. In case of a factory or a company, the production sold and income generated. In case of a motor car, it provides comfort and convenience in transportation. There is no direct income. There is a normally expected life time for the asset during which time is expected to perform. The owner, aware of this, can so manage his affairs that by the end of that life time, a substitute is made available to ensure that the value or income is not lost. However, if the asset gets lost earlier, being destroyed or made non-functional, through an accident or other unfortunate event, the owner and those deriving benefits from it suffer. Insurance is a mechanism that helps to reduce such adverse consequences.

Assets are insured, because they are likely to be destroyed or made non-functional through an accidental occurrence. Such possible occurrences are called perils: fire, floods, break downs, lightening, earthquakes etc. the risk means possibility of loss or damage. Insurance is done against that it may happen. If there is no uncertainty about the occurrence of an event, it cannot be insured against. The mechanism of insurance is very simple as the risk is spread among the community and the likely big impact on it is reduced to smaller manageable impacts on all.

Insurance is transfer and spreading of the risk. In other words, it is pooling of the risk and sharing the loss. Those who survive pay for those who unfortunately die. It is often felt that life insurance means only death insurance. This is not true. Life insurance is insurance against the loss of the income earning capacity of the person. Death, Accident and Sickness (Critical illness only) can affect the income earning capacity of an individual. Life insurance offers protection for the loss of income earning capacity due to death, accident and sickness.

\subsection{Why life Insurance?}

Very often it is said that before you let the worry get into your head, buy Life Insurance.

Why? Life Insurance provides protection to your family - your family gets a specified sum in a lump sum when they need it the most i.e. when you are not around. While the emotional loss cannot be mitigated, the lump sum received from an insurance company can help take care of your family's financial future. Life Insurance policies also offer tax benefits though tax saving should not be the primary reason an individual should look at a Life Insurance policy. Finally, Life Insurance contracts allow an individual to save money in a tax efficient manner and allow savings to grow to help meet our future financial obligations.

\subsection{Benefits of Life Inusrance}

Two of the most important benefits of Life Insurance are protecting loved ones against the FINANCIAL CONSEQUENCES OF THE INSURED'S DEATH and the LIVING BENEFITS OF LIFE INSURANCE.

\section{Financial Consequences of Death}

The financial consequences of death can be devastating. Nothing can replace a spouse, a parent, child, brother or sister. But, the practical and financial consequences of death are another matter. Without life insurance, surviving dependents can suffer extreme financial hardship as a result of an individual's death. There exists the possible loss of future income as well as a number of sudden expenses that occur as a result of death. 


\section{The Consequences of Dying Too Soon}

According to mortality statistics, a certain number of people will die each year before reaching their normal life expectancy. When a breadwinner dies prematurely, the loss to the family can be tragic in so many ways. The survivors are suffering deep personal grief and must face some very serious financial consequences because they can no longer rely on the breadwinner's income. The consequences include:

\section{A. Final Expenses}

We frequently hear about the high cost of living, but dying can be expensive too. Look at some of the common costs that must be met when a person dies:

\section{Funeral Expenses}

Funeral costs can vary widely depending upon the type of service, area of the country and other factors. In addition to the cost of the funeral, there may also be burial expenses (if separate), florist's fees, and prepaid expenses for future care of the burial site. Whatever the costs, they will most certainly increase over time, due to inflation.

\section{Estate Administration}

Executor's fees and fees for the executor's attorney will make up most of this cost. Other expenses may include court or probate costs, the cost of appraising estate property, the cost of insuring estate property while the estate is open, maintenance or repair of estate property; particularly if it is to be sold, the cost of defending a will if it should be contested, auctioneer's fees and so on. The larger and more complex a person's holdings, the larger the administration expenses will likely be. But even modest estates may incur significant administration expenses.

\section{Debts}

This could be another major cost. It includes automobile loan balances, credit card balances, promissory notes, bank loans and final expenses of the last illness - medical expenses that might not be covered by Medicare or health insurance. Accrued taxes may also be considered debts. This would include unpaid income taxes (federal, state and local), property taxes, and any other taxes that were incurred but not paid.

\section{B. Loved Ones' Future Security}

In most cases, there are also obligations that extend into the future-security for those left behind. There may be a spouse who needs living expenses, mortgage payments to be made or children to raise and educate. If the deceased was an income earner, surviving dependents will have to manage without that income. If the deceased stayed at home caring for children, the surviving partner will likely face a substantial increase in expenses to replace the deceased's contributions to the family lifestyle.

No matter how many or what kind of financial obligations an individual leaves at death, there's only one thing that will satisfy them-money. For this reason, a person who wants to relieve his or her family of these obligations will plan to leave them with money sufficient to cover all these needs.

\section{Income Needs}

\section{Dependency Period}

Funds need to be available during a time when it may be hard for the surviving spouse to work due to children. With the high cost of childcare, a surviving spouse may not be able to make enough money to afford childcare expenses.

\section{Survivor's Blackout Period}

The "widow's blackout period" is the period of time during which social security has stopped paying the surviving spouse because there are no longer any dependent children. The widow would no longer receive benefits from social security until age 60 . 


\section{Mortgage Payments/Rent Fund}

The emotional effects of losing a loved one take a long time to get over. Coupled with the need to uproot the family, it could make a difficult time even worse. So, when planning on family financial needs, things to look at are either paying off a mortgage or having enough funds available to make mortgage/rent payments for a period of time.

\section{E. College Education}

Being able to send their children to college and give them the best education possible has always been a dream for parents. The death of one parent should not hamper this dream from taking place. Life insurance proceeds can help pay for children's college education.

\section{Retirement / Savings - Building an Estate}

The following are some ways to build that estate to leave to your loved ones:

\section{A. Life Insurance}

A method of estate building is life insurance. It has the advantage of creating an immediate estate at the time it is most needed-when the insured dies. Another advantage is that it can be tailored to meet the full amount of obligations at death. Life insurance proceeds are generally payable in full to the beneficiary shortly after the insured's death. How much is paid depends upon the death benefit of the policy.

\section{B. Savings}

One could deposit money in a savings account at regular intervals. These savings might provide an estate that could meet all obligations. There are, however, a couple of problems with savings accounts. First, since money can be easily withdrawn, the savings balance may not increase.
A second problem is that one might not live long enough to accumulate sufficient savings to handle all obligations at death. So savings, while a good practice, may not be absolutely relied upon to create an adequate estate.

Third, earnings from savings accounts are taxed as current income, necessitating more deposits to reach retirement objectives.

\section{Other Investments}

Investments can also provide significant returns. Lots of people have created additional savings through securities (such as stocks and bonds) and real estate. But lots of people have also lost money to investments that either failed or did not meet expectations. There are no guarantees when it comes to investments. There's always an element of risk. And just like savings, one might not live long enough for an investment program to create a large enough estate. In some instances, these investments may not be at maximum value when needed.

\section{Life Insurance as the Solution}

If people could predict the future, most would rush out and purchase as much life insurance as they could obtain. Life insurance can provide the money a family needs for continued security when it needs it the most. That's the most important job of life insurance. It provides a new source of cash and income so a surviving family can continue to live in comfort after the death of its primary income earner.

\section{Living Benefits of Life Insurance}

We've talked about the death benefits of life insurance - the benefits the beneficiaries will receive when the insured dies. But life insurance can also provide benefits for the policy owner or insured while he or she is living. Living benefits are another way life insurance can help people. 


\section{Cash Values}

Some types of life insurance policies that last for the entire life of the insured are called permanent insurance. These policies, in addition to their death benefit usually accumulate cash values. Prior to the insured's death, this cash value belongs to the policyowner and can benefit him or her in many ways.

The premiums paid for this kind of life insurance are higher than those paid for term life insurance. Term Insurance pays a death benefit only if the insured dies during the term of the policy and accumulates no cash values.

\section{Withdrawals and Loans}

Some permanent life policies permit withdrawals from the cash value-money to be used by the policy owner for any purpose. The amount withdrawn, however, is generally subtracted from the policy's face amount (the death benefit). The policy owner can also take out loans from the insurance company using the policy's cash value as collateral. The loans must be paid back or the amount of any outstanding loan and interest will be deducted from the policy's face amount when the insured dies.

\section{For Retirement Planning}

When people get older, they may begin to look at their life insurance policies in a different light. What had provided protection against the financial consequences of premature death may now be used to help them enjoy their retirement years. The cash value can be used as additional income during retirement (e.g. to help pay for that trip of a lifetime they've been planning to take, to buy that new car or to help provide college education for grandchildren). It's wise to remember, however, that life insurance is not an investment. Its main purpose is to provide a death benefit. There are other and possibly better ways to save for retirement, but life insurance is unique in that it can offer payment of the full face value of the policy when the insured dies while accumulating a cash value during the insured's lifetime.

\section{For Education Needs}

Similar to retirement needs, cash values may be used for educational needs. Funds could come from a policy taken out on the life of an infant with cash values accumulating until he or she reaches college age. Or it could be part of planning for the future with a policy on the life of one parent or perhaps both parents. The policy protects against the insured's premature death and, in the event he/she lives on, can provide cash values to help pay college costs.

\section{The Consequences of Living Too Long / The Retirement Years}

During 40 or more years of working, a large amount of money can pass through an income earner's hands. Most people's earnings levels do increase over time, through raises, promotions, fringe benefits or incentive plans. And with each increase, they gradually become accustomed to a higher and higher standard of living.

They may :

Purchase a larger home;

Dine out more often;

Buy new cars more frequently;

Provide their children or grandchildren with college educations; or take expensive vacations.

As people reach old age, their earnings begin to diminish. Many people save very little for the future; instead, they live for today and let tomorrow take care of itself.

Financial problems eventually become severe when people attempt to retain the life-style they enjoyed when they had more income. It's like trying to fit a size nine foot into a size five shoe. It hurts. They are forced to face reality; the money won't stretch far enough. They have to either take a part-time job or lower their standard of living considerably. 


\section{Life Insurance as the Solution}

Life insurance products can offer a practical solution to the retirement need. Through the benefits of life insurance, a retired couple need not become dependent on outside sources for their financial care. Life insurance can provide cash or lifetime income.

\section{Review of Literature}

Considering the important role of insurance, the present study is designed to the customer preferences towards life insurance among other saving alternatives. Though various aspects of insurance have been studied so far, not much attention has been paid to this area. A brief survey of the studies done on insurance taking into consideration various aspects including the related ones is presented briefly.

The insurance industry in India has witnessed different eras and is more than 150 years old. From the days when there were several private companies, to nationalization, and to privatization, the industry has come with a full circle. Prior to independence more than two hundred private insurance companies were doing business particularly in life insurance arena. A cursory glance at the pre-nationalization period, through the Indian insurance year books and historical studies amply demonstrates that even with an increasing number of statutory laws and insurance acts passed from time to time - more than 40 times during 1938, 1939, 1940, 1941, 1955, and the Insurance Act 1958 - to regulate and control the business, as many as 66 out of 215 life business companies perished between 1935 and 1955 (Aggarwal, 1961 and Bhave, 1970).

The growing business mismanagement and malpractice, manipulation of life funds to indulge in speculative trading, large scale liquidation of insurance companies, inter - locking of funds, and control and influence of large business houses led to public disenchantment and resentment.

On $19^{\text {th }}$ January 1956 , the government promulgated life insurance (Emergency Provisions) ordinance through which it took temporary charge of the life insurance business of 154 Indian and non-Indian insurers and of 75 provident fund societies operating in the country (Agganwal, 1960). On 18th June 1956, the government brought the bill in the parliament for the formation of LIC. The bill, better known as Life Insurance Corporation of India Act, 1956, came into force on $1^{\text {sl }}$ September 1956 through which the government took over the life insurance business of the country. The LIC is a monopolistic and monolithic institution, the only exception being the postal life insurance and a few compulsory schemes of life insurance for state employees managed by some state governments.

In India, after freedom, five-year plans were launched which require substantial funds. The need to extend the benefits of life insurance to rural and neglected society was also widely felt. At the same time the controller of insurance received serious complaints of misuse of funds by the insurance companies. These factors prompted the government to nationalize the life insurance business in India. Edmister (1987) opines that insurance is a mechanism, which involves two fundamental characteristics, viz., transferring and shifting risk from one individual to a group and sharing losses on some equitable basis by all members of the group. Insurance companies using the law of large numbers predict what percentage of persons of a group would die at a certain age and thus prepare tables containing these percentages called Mortality Statistics. These Mortality Statistics are an important aspect of portfolio management of the company because the timing and frequency of death affect the timing and amount of liquid asset that the company needs. 
By an act of parliament, the Life Insurance Corporation (LIC) was formed with capital contribution of Rs. 5 crore from the Government of India. Thus nationalization aimed at overcoming the inefficiency and malpractices prevalent during the period of private insurance operations; to make insurance widespread under government; to restore public confidence and to ensure maximum security to the policyholder's capital.

In the changing socio-economic milieu, changing institutional and legal structure, burgeoning middle class coupled with increasing pension less old; a better service from the insurance industry is called for. Though LIC and GIC have done some commendable job in spreading the insurance business across the country, they still fall short of international standards in terms of technical and managerial skills, cost efficiency (higher premium) and product range and hence innovation. It is estimated that less than 23 percent of the insurable population is covered by life insurance policies (Jha, 1995).

Recognizing the importance of insurance sector as an important source of low cost term funds, the government has taken steps to open up the insurance sector. The Insurance Regulatory Authority (IRA) Bill allows 26 percent foreign equity in domestic insurance companies and additional 14 percent by investors comprising Non-Resident Indians, Overseas Corporate Bodies and Flls (Report on Development Banking in India, 1998).

Increase in productivity and demand for insurance services would require a more skilled labour force. Increased volume of business would certainly lead to an increase in employment contrary to the fears of trade unions. The data suggests that the developed countries employ more labour than the Indian Insurance Industry (Ranade and Ahuja, 1998).
Millions of small and middle class savers buy insurance policies not merely to take care of them in their old age but more importantly for their dependants, i.e., the policies are intergenerational in nature and hence the problem has a temporal dimension.

For instance, a small policyholder opts for a policy that can take care of his/her son/daughters education or marriage after a certain period of time. Therefore, in the period of crisis, the social costs of failure exceed the private costs and these are potentially debilitating consequences for the economy as a whole (Goodheart et al. 1998). The main apprehension of the privatization of insurance sector is that it will erode the "social cause" of the Indian Insurance Industry by making profitability the ball game instead of social development. It is imperative to mention here that LIC and GIC own a total fund of more than Rs. 1 , 50,000 crore together and have invested a combined Rs. 25000 crore in social sector.

Bhole (1999) comments that historically, Life Insurance Corporation of India and General Insurance Corporation of India dominate insurance sector. The Government set up the Malhotra Reforms Committee in 1993 to make recommendations for reforms and privatization in Indian Insurance. Consequent to it, this six international Insurance chains were allowed to enter the Indian Insurance Market in early 1996 by tying up with India's leading industrial groups but this process of privatization suffered a set back when the Insurance Regulatory Authority (IRA) Bill was withdrawn.

According to Muthy (2001), Insurance companies, in order to provide comfort to the society in an organized manner, basically undertake three functions, viz., risk taking, asset management and servicing the customers. He emphasized some of the challenges likely to be faced by insurance companies while doing business. 


\section{Research Methodolgy}

This research under consideration is an attempt to study the customer preferences towards life insurance among other saving alternatives, with the following objectives.

\section{Objectives of the study :}

The study is conducted with the following objectives:

- Benefits of life insurance over other saving options

- Customer preferences towards life insurance.

Scope of study : This study is conducted in commercial location in New Delhi, which is Cannaught place, regarded as Central Business District (CBD) by collecting primary data through Questionnaires.

Nature of Research : The study is of an analytical nature as the customer preference towards life insurance as a saving tool will be analyzed. It is also a hypothesis testing research, as hypothesis are developed as follows :

Hypothesis 1: - Life Insurance is preferred by all among all other saving options

Hypothesis 2: - Customers prefer to purchase life insurance plans from Life Insurance Corporation of India

Sample Selection : The purposive sampling has been used for selecting offices from the universe.

SAMPLE SIZE: 500

3 Data Analysis and Interpretation

1. Age of the Respondents

Table 1

\begin{tabular}{|l|c|c|}
\hline PARTICTULARS & NO.OF.RESPONDENT & PERCENTAGE \\
\hline Less than 25 & 55 & $11 \%$ \\
\hline $25-35$ & 200 & $40 \%$ \\
\hline $35-45$ & 100 & $20 \%$ \\
\hline Above 45 & 145 & $29 \%$ \\
\hline TOTAL & $\mathbf{5 0 0}$ & $\mathbf{1 0 0}$ \\
\hline
\end{tabular}

Analysis :

From the survey it was found that amongst 500 respondents

a) $11 \%$ of the respondents are less than 25 years old.

b) $40 \%$ of the respondents are between 25 and 35 years of age.

c) $20 \%$ of the respondents are between 35 and 45 years of age.

d) $29 \%$ of the respondents are more than 45 years of age. 
2) Occupation of the Respondents

Table 2

\begin{tabular}{|l|c|c|}
\hline PARTICULARS & NO.OF.RESPONDENT & PERCENTAGE \\
\hline Business man & 170 & $34 \%$ \\
\hline Professionals & 90 & $18 \%$ \\
\hline Job holders & 185 & $37 \%$ \\
\hline Others & 55 & $11 \%$ \\
\hline TOTAL & $\mathbf{5 0 0}$ & $\mathbf{1 0 0 \%}$ \\
\hline
\end{tabular}

\section{Analysis :}

From the survey it was found that amongst 500 respondents

a) $34 \%$ of the respondents are businessmen.

b) $18 \%$ of the respondents are professionals.

c) $37 \%$ of the respondents are jobholders.

d) $11 \%$ of the respondents are background.

\section{3) Average Annual Income of Respondents}

\section{Table 3}

\begin{tabular}{|l|c|c|}
\hline PARTICULARS & NO.OF.RESPONDENT & PERCENTAGE \\
\hline Up to 1 lakh & 165 & $33 \%$ \\
\hline 1 lakh - 3 lakh & 215 & $43 \%$ \\
\hline 3 lakh - 5 lakh & 100 & $20 \%$ \\
\hline 5 lakh \& above & 20 & $4 \%$ \\
\hline TOTAL & $\mathbf{5 0 0}$ & $\mathbf{1 0 0 \%}$ \\
\hline
\end{tabular}

\section{Analysis :}

From the survey it was found that amongst 500 respondents
a) $33 \%$ of the respondents have an average annual income up to 1 lakh
b) $43 \%$ of the respondents have an average annual income from 1 lakh to 3 lakh
c) $20 \%$ of the respondents have an average annual income from 3 lakh to 5 lakh
d) $4 \%$ of the respondents have an average annual income above 5 lakh 
4) Percentage of the Respondents having Life Insurance Policy.

Table 4

\begin{tabular}{|l|l|c|}
\hline PARTICULARS & NO.OF.RESPONDENT & PERCENTAGE \\
\hline Yes & 280 & $56 \%$ \\
\hline No & 220 & $44 \%$ \\
\hline TOTAL & 500 & $100 \%$ \\
\hline
\end{tabular}

\section{Analysis :}

From the survey it was found that amongst 500 respondents

Only $56 \%$ have taken life insurance policy and out of these $56 \%$ means 280 respondents -

5) Percentage of Respondents towards Selection of Life Insurance Company for policy purchase.

Table 5

\begin{tabular}{|l|c|c|}
\hline PARTICULARS & NO.OF RESPONDENT & PERCENTAGE \\
\hline Life Insurance Corporation of India & 216 & $77 \%$ \\
\hline ICICI Prudential & 20 & $7 \%$ \\
\hline HDFC Standard Life Insurance & 11 & $4 \%$ \\
\hline Reliance Life Insurance & 11 & $4 \%$ \\
\hline Bajaj Allianz Life Inșurance & 8 & $3 \%$ \\
\hline MAX New York Life Insurance & 14 & $5 \%$ \\
\hline TOTAL & $\mathbf{2 8 0}$ & $\mathbf{1 0 0 \%}$ \\
\hline
\end{tabular}

\section{Analysis :}

From the survey it was found that amongst 280 respondents

1. $77 \%$ respondents have bought insurance plan from LIC

II. $7 \%$ respondents have bought insurance plan from $\mathrm{ICICl}$ prudential

III. $4 \%$ respondents have bought insurance plan from HDFC Standard Life Insurance

IV. $4 \%$ respondents have bought insurance plan from Reliance Life Insurance

V. $3 \%$ respondents have bought insurance plan from Bajaj Allianz Life Insurance

V1. $5 \%$ respondents have bought insurance plan from MAX New York Life Insurance 
6) To Which Sector You Will Give Preference While Investing at Present

Table 6

\begin{tabular}{|l|c|c|}
\hline PARTICULARS & NO.OF.RESPONDENT & PERCENTAGE \\
\hline Insurance Investment Plan & 100 & $20 \%$ \\
\hline Stock market & 50 & $10 \%$ \\
\hline Govt. Deposits & 100 & $20 \%$ \\
\hline Bank Deposits & 105 & $21 \%$ \\
\hline Mutual Fund & 75 & $15 \%$ \\
\hline Real estate & 70 & $14 \%$ \\
\hline TOTAL & $\mathbf{5 0 0}$ & $\mathbf{1 0 0} \%$ \\
\hline
\end{tabular}

Analysis :

From the survey it was found that amongst 500 respondents

i. $20 \%$ of the respondents prefer to invest in Insurance Investment Plan.

ii. $10 \%$ of the respondents prefer to invest in Stock market.

iii. $20 \%$ of the respondents prefer to invest in Govt. Deposits.

iv. $21 \%$ of the respondents prefer to invest in Bank Deposits.

v. $15 \%$ of the respondents prefer to invest in Mutual Fund

vI. $14 \%$ of the respondents prefer to invest in Real estate.

\section{CHI-SQUARE TEST}

Hypothesis Stated : 1

"Customer Prefers To Purchase Life Insurance Plans From Life Insurance Corporation Of India." This Statement Is Expected To Be Believed $\mathbf{9 0 \%}$, And Observed As $77 \%$.

Null Hypothesis: The difference observed is significant, and the difference is due to the Sampling

Alternate Hypothesis: The difference observed is insignificant. So, the Observed percentage should be the actual value for Customer preference to purchase life insurance plans Life Insurance Corporation of India.

\section{CHI - SQUARE TEST}

Customer Prefers To Purchase Life Insurance Plans from Life Insurance Corporation of India (\% AGE)

\begin{tabular}{|l|l|c|}
\hline (Expected) & (Observed) & {$\left[(O-E)^{\wedge} 2\right] / E$} \\
\hline 90 & 77 & 1.8777 \\
\hline
\end{tabular}

DEGREE OF FREEDOM, $d f=(n-1)=1$ 


\section{CRITICAL VALUE $=3.84$}

(Value of CHI-SQUARE For $5 \%$ Level for One Degree of Freedom Is 3.84)

HERE CRITCAL VALUE IS GREATER THAN THE CALCULATED VALUE.

\section{ACCEPT THE NULL HYPOTHESIS, i.e.}

Customer prefers to purchase life insurance plans from Life Insurance Corporation of India. This statement is expected to be believed at $90 \%$, and observed as $77 \%$. And the difference is due to the Sampling.

\section{HYPOTHESIS STATED: 2}

\section{"Investment In Life Insurance Plans Is Preferred By All Among Other Saving Alternatives."}

Null Hypothesis: The difference observed is significant, and the difference is due to the Sampling.

Alternate Hypothesis: The difference observed is insignificant. So, the Observed percentage should be the actual value for Customer investment preference towards life insurance plans among other saving alternatives.

\section{CHI - SQUARE TEST}

All among Other Saving Alternatives Prefers Investment in Life Insurance Plans (\%Age)

\begin{tabular}{|l|l|l|l|}
\hline (Option) & (Expected) & (Observed) & {$\left[(O-E)^{\wedge} 2\right] / E$} \\
\hline 1.Insurance Investment Plans & 16.7 & 20 & 0.65 \\
\hline 2.Stock Market & 16.6 & 10 & 2.62 \\
\hline 3.Govt. Deposits & 16.7 & 20 & 0.65 \\
\hline 4.Bank Deposits & 16.6 & 21 & 1.166 \\
\hline 5.Mutual Fund & 16.7 & 15 & 0.173 \\
\hline 6. Real State & 16.7 & 14 & 0.436 \\
\hline & 100 & 100 & 5.6955 \\
\hline
\end{tabular}

DEGREE OF FREEDOM, $d f=(6-1)=5$

CRITICAL VALUE $=11.07$

(Value of CHI-SQUARE for $5 \%$ level for five degree of freedom is 11.07 ) 


\section{Here Critical Value Is Greater Than The Calculated Value.}

ACCEPT THE NULL HYPOTHESIS, i.e.

Among other saving alternatives, investment in Life Insurance Plans is preferred because our calculated value is less than critical value. So our null hypothesis is with in the range.

\section{CONCLUSIONS}

As of now we understand the changing dimensions of insurance and how it is being value add in terms of investment alternative. And that the insurance policies are pegged high on the scale of an investment plan because they work as saving schemes give us guaranteed cash payments annually and also provide a risk cover to us and our family.

\section{REFERENCES}

Aggarwal, A.N.. "Insurance in India", Law Journal of Press Allahabad, (1960), p.350.

Ahuja, R., Bundling Savings and Insurance : Reasons and Implications; IGIDR Discussion Paper No. 99/154 (1958).

Bajpai, O.P., Elements of Life Insurance, Ist ed. (Allahabad: Kitab Mahal, 1959).

Barrese, James, Gardner, Lisa, Trower, Ellen, "Changing Attitude About Insurance through Education". CPCU Journal, Fall, 51, No. 3 (1998), pp. 144-159.

Klein, R.A., "New Frontiers", Asian Insurance Post, July 2001.

Kothari, N.S. and Bahl, Principle and Practice of Insurance, (Agra: Sahitya Bhawan, 1990).

Madhu, T., "We are ready for our rivals", Intelligent Investor, Feb. 2001, pp. 1-15.
Mishra, M.N., Life Insurance Corporation of India in Marketing Management, Vol. 1 (Jaipur : RBSA Publishers, 1991).

Meder, R.C., "Changes in the Global Insurance Market", ICFAI Reader, May 2001.

Mehlwal,G., "The Face of the Insurance Industry in India", The ICFAl Insurance Chronicle, January 2006, pp. 57-63.

Parera, R.I., "Challenges and Opportunities: Privatization of Insurance", The Chartered Accountant, January 2001

Ramakrishanan, R., "Insurance Setting the Record Straight", The Hindu: Survey of Indian Industry 1999, Chennai (2000), pp. 54-58.

Report of the Committee on Reforms in the Insurance Sector, Ministry of Finance, Government of India (1994).

\section{Internet Sources:}

www.licindia.com

www. irdaindia.org/regulations

www.indiainfoline.com/content/insurance/

life_insurance

www.economywatch.com/indianeconomy/

indian_insurance_Sector.html_30K

http://www.kampusonline.biz/qes/webenar/

u_wblist2.aspx?tod=Cll001000074

www.ficci.com/media-room/speeches-

presentations/2002/sep/sep-insurance-sbi.ppt -

http://www.thehindubusinessline.com/2004/10/

01/stories/2004100101880600.htm/ 